HELMINTHOLOGIA, 52, 4: 323 - 330, 2015

\title{
Monogenean parasites of Lepomis gibbosus Linnaeus introduced into the River Durance, France
}

\author{
L. HAVLÁTOVÁ', M. ONDRAČKOVÁ1* I. PŘIKRYLOVÁ2,3
}

\begin{abstract}
${ }^{1}$ Institute of Vertebrate Biology, Academy of Sciences of the Czech Republic, Květná 8, 603 65, Brno, Czech Republic,
*E-mail: audrey@sci.muni.cz; ' Department of Botany and Zoology, Faculty of Science, Masaryk University, Kotlárská 2, 611 37, Brno, Czech Republic, ${ }^{3}$ Department of Biodiversity, University of Limpopo, Turfloop Campus, Private Bag X1106, Sovenga 0727, South Africa
\end{abstract}

Article info

Received March 19, 2015 Accepted June 17, 2015

\begin{abstract}
Summary
The pumpkinseed, Lepomis gibbosus Linnaeus (Centrarchidae), was introduced into the Europe from North America in late 19th century. In this study, we examine monogenean parasites of $L$. gibbosus from the River Durance in France. We found seven parasite species introduced together with the host: Actinocleidus recurvatus, A. oculatus, Onchocleidus similis, O. dispar, 0. acer, Cleidodiscus robustus (Ancyrocephalidae) and Gyrodactylus macrochiri (Gyrodactylidae). Early diporpa (Diplozoidae), accidentally attached to the gills, represent a single parasite species acquired within the area of introduction. Three species, O. acer, C. robustus and G. macrochiri, are reported from Europe for the first time.
\end{abstract}

Keywords: non-native fish; invasive species; parasites; sunfish; Monogenea; host introductions

\section{Introduction}

The pumpkinseed, Lepomis gibbosus Linnaeus (Centrarchidae) is native to the eastern part of North America. The species is one of the most successfully introduced freshwater fish species, having now spread throughout the European mainland. Since its introduction, $L$. gibbosus has become established in at least 28 countries in Europe and western Asia (Copp \& Fox, 2007). It was first introduced into France from Canada in 1877 as an ornamental aquarium and garden pond fish (Arnold, 1990). At present, the species occurs in the Lower Rhône, from the River Saône to the River Isère and in the River Durance (Olivier, 2009).

To date, occurrence of five monogenean species has been reported from European populations of $L$. gibbosus: ancyrocephalids Onchocleidus similis Mueller, 1936; O. dispar Mueller, 1936 (classification based on Beverley-Burton \& Klassen, 1990); Actinocleidus recurvatus Mizelle and Donahue, 1944; and A. oculatus (Mueller, 1934), all introduced together with the fish host (e.g. Galli et al., 2005). In addition, a gyrodactylid Gyrodactylus sp. from the laevis/prostae group was most probably acquired in the species' new range (Ondračková et al., 2011). Both Onchocleidus species also carry the generic synonyms Urocleidus and Cleidodiscus (Mizelle \& Hughes, 1938; Price \& Mure, 1969), while O. dispar also has a third synonym Haplocleidus dispar, Mueller, 1937. Presence of monogeneans in parasite communities of European L. gibbosus has been confirmed in the Danube River Basin (Roman, 1953; Kiškaroly, 1977; Grupcheva \& Nedeva, 1999; Ondračková et al., 2011), and in Italy (Galli et al., 2005) and France (Lambert, 1979). They have also been recorded in newly established populations in colder regions such as Norway (Sterud \& Jørgensen, 2006) or England (Hockley et al., 2011). On the other hand, monogenean parasites were absent at some other sites, such as the warm-water discharge canal of the Szczecin Power Plant in the Oder River Basin, Poland (Piasecki \& Falandysz, 1994), or in the River Elbe near the city of Pardubice, Czech Republic (Ondračková, unpublished data).

Despite its relatively wide distribution and established presence in many parts of Europe, our knowledge about the parasitic fauna of $L$. gibbosus remains relatively poor. In this study, we focus on the monogenean parasites of $L$. gibbosus in France, collected from the region of primary introduction, where the host species has been established for more than a hundred years.

\section{Materials and Methods}

Lepomis gibbosus were sampled by electrofishing from a small 
backwater of the River Durance near the village of Pertuis, France $\left(43^{\circ} 40^{\prime} 07.8^{\prime \prime} \mathrm{N}, 5^{\circ} 29^{\prime} 16.5^{\prime \prime} \mathrm{E}\right)$. Fish were collected at sites of 30 $50 \mathrm{~cm}$ depth and almost zero velocity. Twelve specimens were collected, seven in June 2007 and five in September 2010. The fish were transported alive in aerated river water to the laboratory and individually sacrificed prior to dissection within $24 \mathrm{~h}$ of transport. Fish length was measured to the nearest $1 \mathrm{~mm}$ and fish weight to the nearest $1 \mathrm{~g}$ (Table 1). The gills, fins and body surface were then examined for the presence of monogenean parasites.

Table 1. Total weight and total and standard lengths of Lepomis gibbosus collected in 2007 and 2010 from the River Durance (France)

\begin{tabular}{lcccc}
\hline & \multicolumn{2}{c}{$2007(\mathrm{~N}=7)$} & \multicolumn{2}{c}{$2010(\mathrm{~N}=5)$} \\
& Mean & Range & Mean & Range \\
\hline Total weight $(\mathrm{g})$ & 23.8 & $(6.5-65)$ & 16.9 & $(9.7-18)$ \\
Total length $(\mathrm{mm})$ & 101.6 & $(73-150)$ & 95.4 & $(81-111)$ \\
Standard length $(\mathrm{mm})$ & 82.9 & $(60-125)$ & 78.0 & $(64-91)$ \\
\hline
\end{tabular}

Any parasites found were removed from the host tissue, fixed in a mixture of ammonium picrate and glycerine (Malmberg, 1970) and mounted on Canada balsam for further analysis (Lim \& Gibson, 2008). Individual parasite species were identified according to the shape and size of the sclerotised structures of the haptor (anchors, connective bars and marginal hooks) and reproductive organs (copulatory organ and vaginal armament) (Beverley-Burton, 1984; Gusev, 1985) using an Olympus BX 51 light microscope equipped with phase contrast and differential interference contrast. Draw-

A

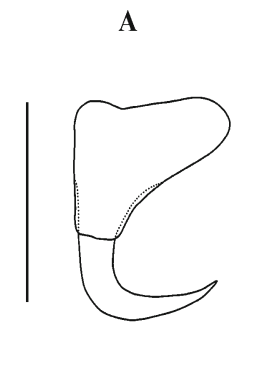

B

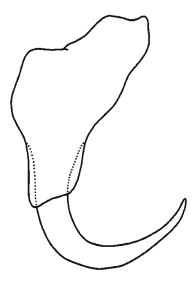

ings of the haptoral hard structures were produced with the aid of a drawing attachment and phase-contrast optics. We measured the haptoral hard structures of 10 individuals per species whenever possible. Measurements were taken using the digital image analysis package Microlmage 4.0 for Windows (Olympus Optical co., Hamburg, Germany). All measurements are presented in micrometres.

\section{Results}

A total of 1261 monogenean parasites were collected, comprising of seven species from two families. Actinocleidus oculatus; $A$. recurvatus; Cleidodiscus robustus Mueller, 1934; Onchocleidus acer Mueller, 1936; O. dispar and O. similis (Ancyrocephalidae) were found on the gills and Gyrodactylus macrochiri Hoffman \& Putz, 1964 (Gyrodactylidae) was found on both the gills and fins. In addition, one diplozoid species in the early larval stage (diporpa with one pair of clamps) was found on the gills. Unfortunately, it was impossible to determine such an early stage larvae to species level. Monogenean parasites infected $L$. gibbosus with an overall abundance of 122.7 in 2007 and 80.4 in 2010. Parasite species richness was slightly higher in 2007 (eight spp.) compared to 2010 (five spp.). Two species ( 0 . similis and $A$. oculatus) had a maximum prevalence of $100 \%$ and a relatively high abundance, while four species (O. acer, O. dispar, C. robustus and G. macrochiri) were generally recorded with low prevalence and abundance (Table 2). The morphology and measurements of haptor and copulatory organ hard parts of the monogenean species previously found in Europe (i.e. O. similis, O. dispar, A. oculatus and A. recurvatus) corresponded to that from the other native and non-native Europe-
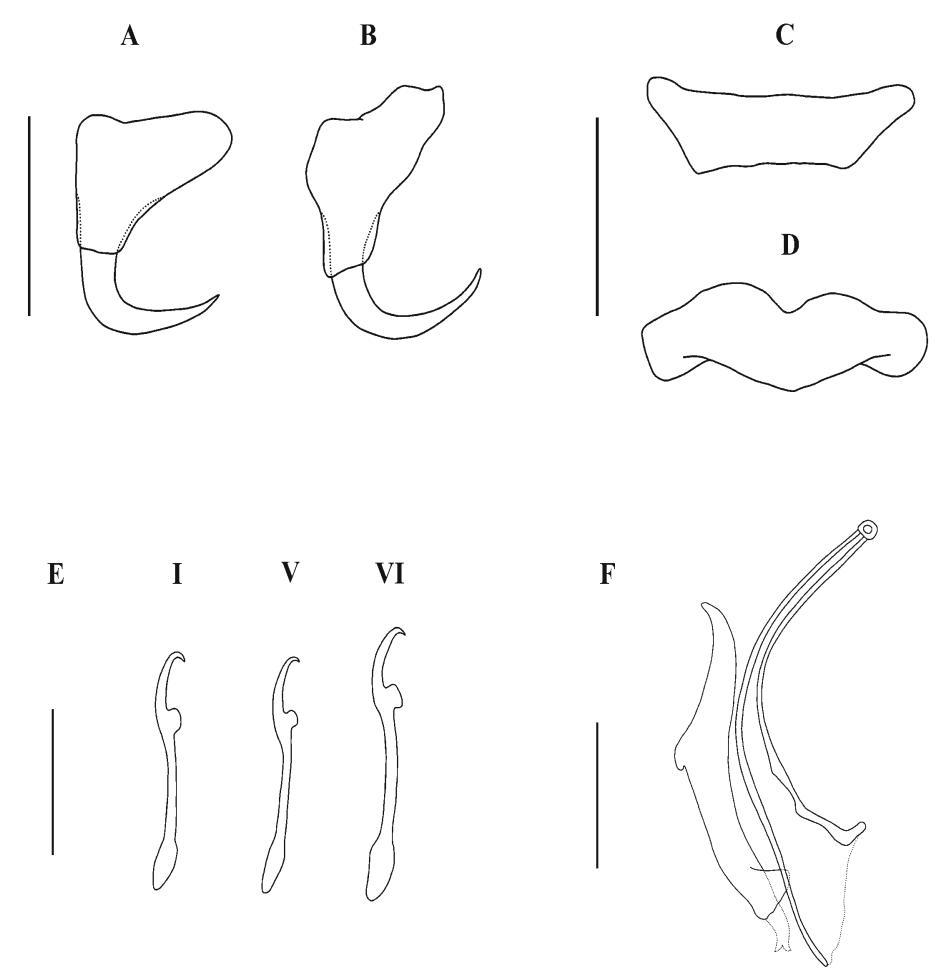

Fig. 1. Cleidodiscus robustus. A) dorsal anchor; B) ventral anchor; C) dorsal bar; D) ventral bar; E) hooks; F) male copulatory organ. Scale bar $=20 \mu \mathrm{m}$ (anchors and bars), $10 \mu \mathrm{m}$ (E and $\mathrm{F}$ ) 
Table 2. Prevalence and mean abundance of monogenean parasites from Lepomis gibbosus collected during sampling in 2007 and 2010 on the River Durance (France)

\begin{tabular}{lcccccc}
\hline & \multicolumn{2}{c}{ Prevalence (\%) } & \multicolumn{3}{c}{ Mean abundance (range) } \\
& 2007 & 2010 & \multicolumn{2}{c}{2007} & 2010 \\
\hline Actinocleidus oculatus & 100 & 100 & 50.7 & $(10-167)$ & 25.8 & $(16-37)$ \\
A. recurvarus & 71.4 & 60 & 25.7 & $(0-85)$ & 4.4 & $(0-10)$ \\
Onchocleidus similis & 100 & 100 & 40.9 & $(5-173)$ & 50.0 & $(23-72)$ \\
O. dispar & 14.3 & 20 & 0.1 & $(0-1)$ & 0.2 & $(0-1)$ \\
O. acer & 14.3 & 0 & 0.1 & $(0-1)$ & 0.0 & 0 \\
Cleidodiscus robustus & 57.1 & 20 & 1.4 & $(0-3)$ & 0.2 & $(0-1)$ \\
Gyrodactylus macrochiri & 57.1 & 0 & 3.6 & $(0-12)$ & 0.0 & 0 \\
Diplozoidae fam. sp. & 14.3 & 0 & 0.1 & $(0-1)$ & 0.0 & 0 \\
\hline
\end{tabular}

an populations (Tables $3 \&$ 4). Three species, C. robustus, O. acer and G. macrochiri, reported here are for the first time in Europe. Hence, we present further details on their morphology below.

Cleidodiscus robustus Mueller, 1934 (Fig. 1)

General morphology based on 5 specimens: Adult body 1100$1600 \mu \mathrm{m}$ long, large and robust compared to most other ancyrocephalids from North American freshwater fish. Two pairs of hamuli of similar shape and dimension; simple transverse bars not articulating with each other. Marginal hooks of similar size and shape. Copulatory organ comprised of sclerotised tubular penis with inflated base and well-sclerotised accessory piece with distal, finger-like projection and bifid base. Penis is $90-95 \mu \mathrm{m}$ long. Vagina with proximal spines, opening on left side of body, lead to the seminal receptacle. Vitellaria coextensive with intestine extends laterally to body margin.

Measurements for $C$. robustus from the non-native population of L. gibbosus in the River Durance are compared with those for a native population reported by Hanek \& Fernando (1972) in Table 3. Type host: L. gibbosus
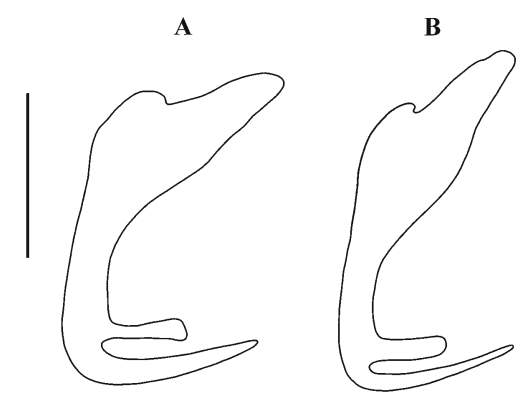

C
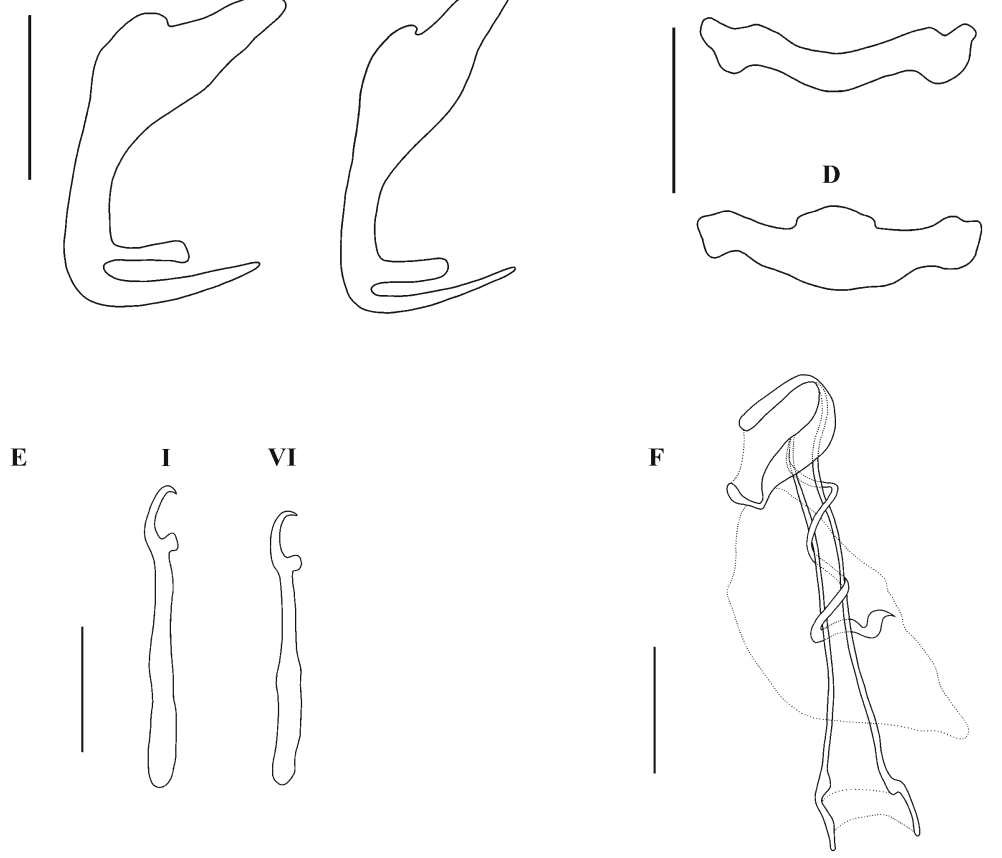

Fig. 2. Onchocleidus acer. A) dorsal anchor; B) ventral anchor; C) dorsal bar; D) ventral bar; E) hooks; F) male copulatory organ. Scale bar $=20 \mu \mathrm{m}$ (anchors and bars), $10 \mu \mathrm{m}$ (E and F) 


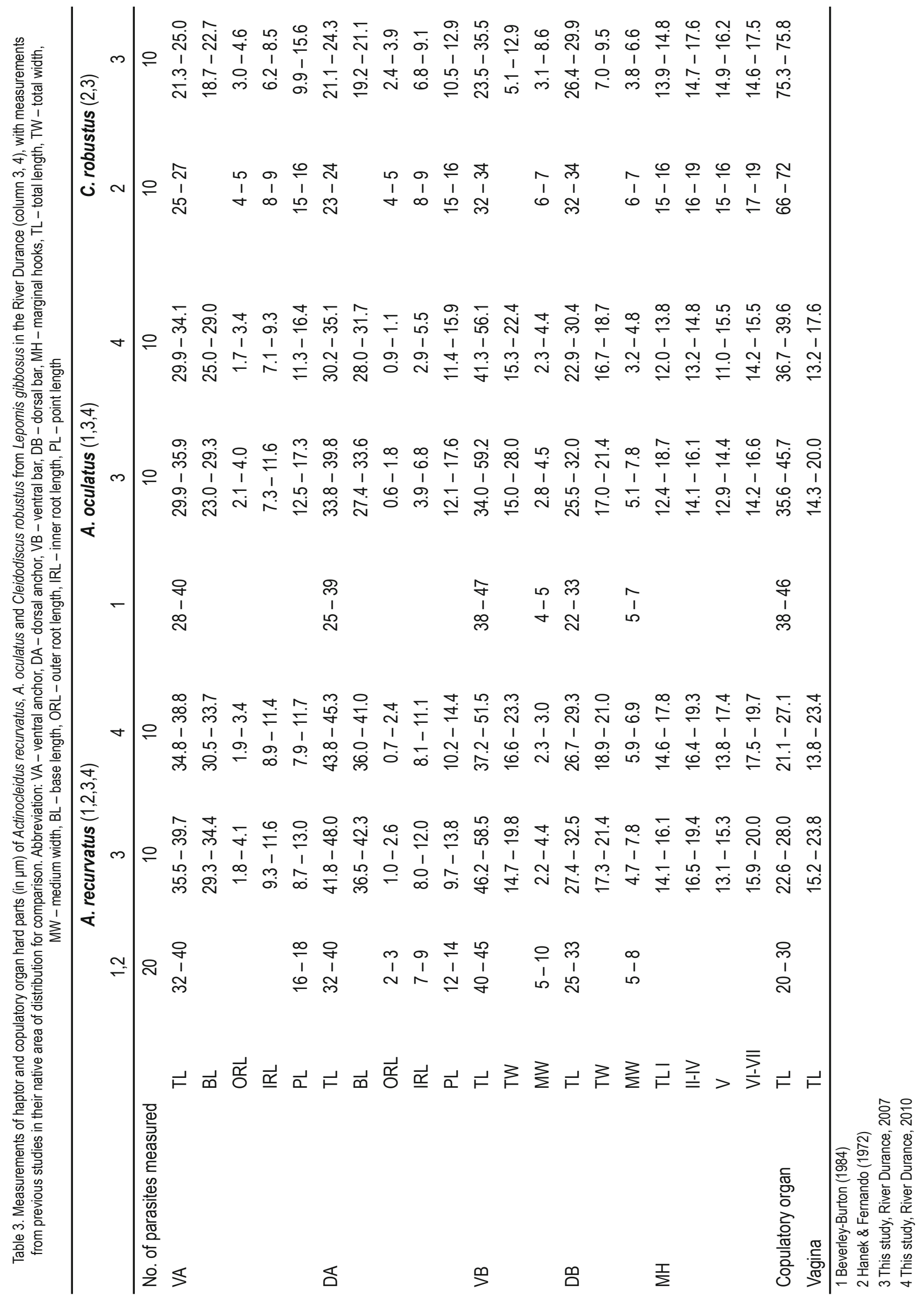



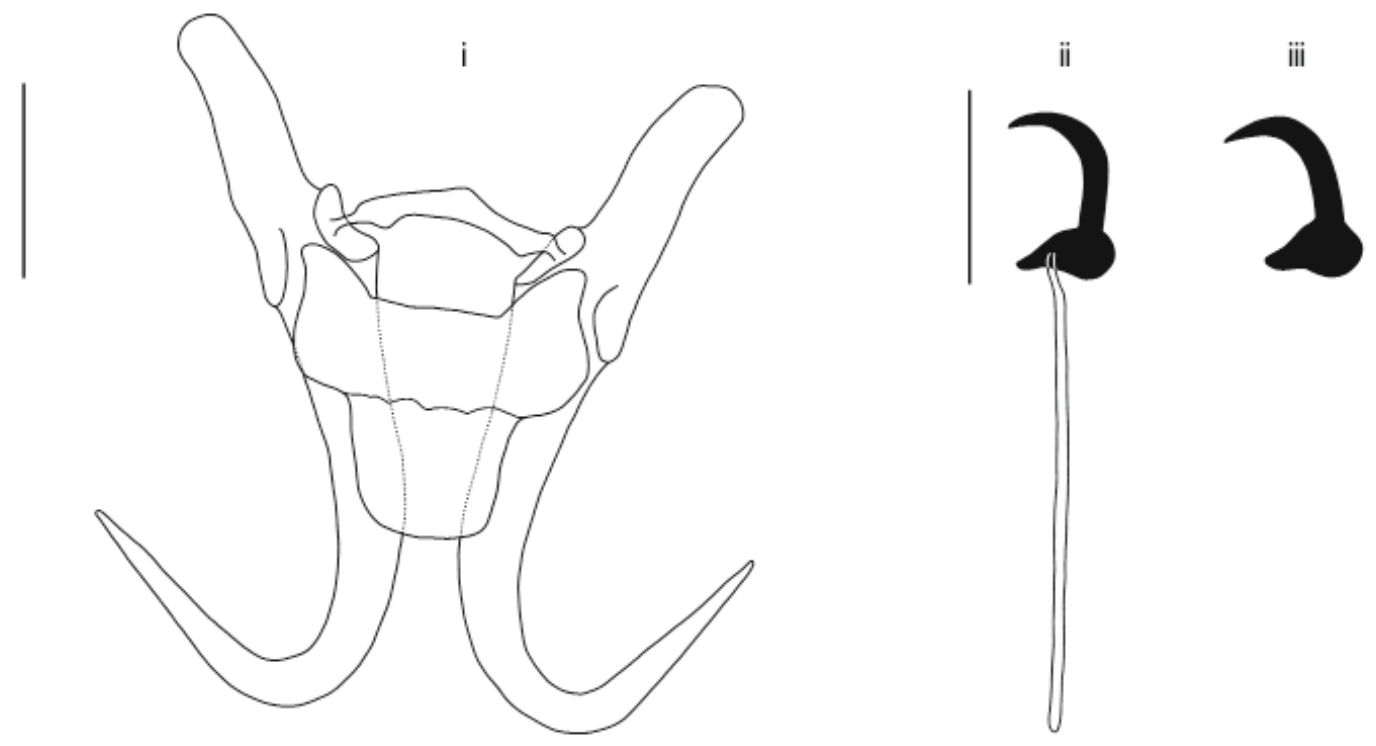

Fig. 3. Gyrodactylus macrochiri. i) complex of central hooks with ventral and dorsal bar, scale bar $=20 \mu \mathrm{m}$; ii) marginal hook; iii) marginal hook sickles detail, scale bar $=10 \mu \mathrm{m}$

Other hosts: L. macrochirus

Specimens deposited: Institute of Parasitology, Biology Centre, Academy of Sciences of the Czech Republic, v.v.i. Branisovska 3137005 České Budejovice, Czech Republic (ICPAS; Coll. No. M-539).

Onchocleidus acer Mueller, 1936 (Fig. 2)

General morphology based on one specimen: Two pairs of hamuli, each with flat finger-like projection on inner curve of blade. Transverse bars not articulating with each other. Marginal hooks of similar shape but slightly different size. Copulatory organ comprised of sclerotised, tubular penis with inflated base and two spiral filaments supporting voluminous sheath. Lightly sclerotised vagina has opening on right side of body leading to the seminal receptacle. Vitellaria coextensive with intestine and extends laterally to body margin.

Measurements for 0 . acer from the non-native $L$. gibbosus population in the River Durance are compared with those for a native population reported by Beverley-Burton \& Suriano (1980a) in Table 4.

Type host: L. gibbosus

Other hosts: L. auritus, L. macrochirus, L. madinatus, L. megalotis, L. microlophus

Specimens deposited: IPCAS M-538

Gyrodactylus macrochiri Hoffman \& Putz, 1964 (Fig. 3)

General morphology based on 10 specimens: Body is small, elongate, comprising of prohaptor and opisthaptor. Hamuli with elongate superficial root. Marginal hook sickles crescent-shaped. Proper sickle arises from base slightly forward and curves regularly. Base shows distinct heel. Anterolateral processes of ventral bar less prominent, projecting laterally. Ventral bar membrane of wide tongue shape.
Measurements for $G$. macrochiri from the non-native $L$. gibbosus population in the River Durance are compared with those for a native population reported by Hanek \& Fernando (1971) in Table 5. Type host: L. macrochirus

Other hosts: Cottus bairdii, L. cyanellus, L. gibbosus, L. gulosus, L. humilis, L. punctatus, Micropretus dolmieui, M. salmoides Specimens deposited: IPCAS M-540

\section{Discussion}

In its native range, L. gibbosus hosts a wide spectrum of monogenean parasites, including 11 valid Ancyrocephalidae species and two Gyrodactylidae species (Beverley-Burton, 1984; Hoffman, 1998). Despite L. gibbosus being present in Europe for more than 100 years (Welcomme, 1981), its monogenean fauna remains relatively poor, with just a single species, 0 . similis, occurring frequently throughout European populations. To date, five monogenean species (four ancyrocephalids and one gyrodactylid) have been reported from $L$. gibbosus in Europe. Four ancyrocephalids, A. oculatus, $A$. recurvatus, 0 . similis, 0 . dispar, were introduced into Europe together with their host L. gibbosus (Gusev, 1985; Galli et al., 2005; Hockley et al., 2011; Ondračková et al., 2011). The single undetermined Gyrodactylus sp. (of the prostae/laevis group) found was probably acquired in its new range (Ondračková et al., 2011). This extremely rare occurrence of parasite acquisition indicates a low susceptibility to the local monogenean species by L. gibbosus. This corresponds with the results of this study from the River Durance, where the majority of monogenean parasites recorded were those introduced with the fish host and only one accidentally attached larval diplozoid was recorded.

All four previously reported ancyrocephalid species from Europe were also found in this study. Of these, 0 . similis was the most frequent species and occurred at highest abundances. This spe- 


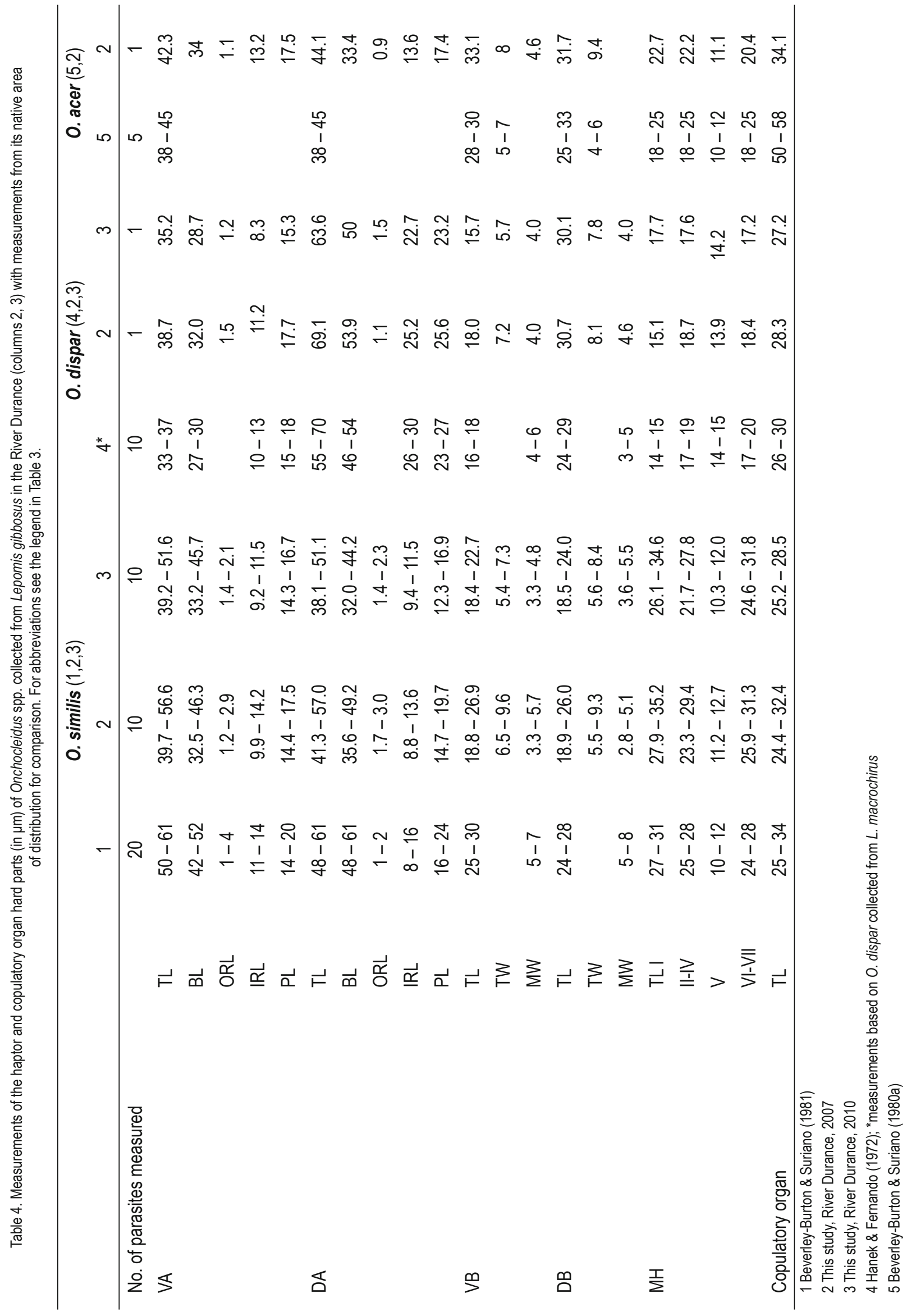


Table 5. Measurements of the opisthaptor hard parts (in $\mu \mathrm{m}$ ) of Gyrodactylus macrochiri from non-native Lepomis gibbosus from the River Durance, with measurements from its native area of distribution for comparison

\begin{tabular}{llcc}
\hline & & \multicolumn{2}{c}{ G. macrochiri } \\
\hline Number of parasites measured & 1 & 2 \\
Anchor & Total length & 10 & 10 \\
& Base & $63-69$ & $67.0-70.3$ \\
& Inner root & $45-51$ & $50.7-53.5$ \\
\multirow{3}{*}{ Ventral bar } & Point & $19-22$ & $18.6-21.5$ \\
& Total length & $27-30$ & $26.0-28.2$ \\
& Total width & $26-29$ & $26.2-31.1$ \\
Dorsal bar & length membrane & & $13.2-18.3$ \\
& Total length & $14-18$ & $14.4-17.6$ \\
Marginal hook & Total width & $23-26$ & $21.3-27.3$ \\
& Total length & & 5.7 \\
\hline & Hooklet & $35-37$ & $34.5-37.1$ \\
\hline
\end{tabular}

1 Hanek and Fernando (1971)

2 This study, River Durance, 2007

cies has been documented in many other European populations of $L$. gibbosus, including those from the Danube River Basin (Roman, 1953; Kiškaroly, 1977; Moravec, 2001; Ondračková et al., 2011), the River Po (Galli et al., 2005) and the recently established population in Norwegian ponds (Sterud \& Jørgensen, 2006). What is more, 0 . similis has been repeatedly reported on other introduced fish such as Prussian carp Carassius gibelio Bloch in Bulgaria (Grupcheva \& Nedeva, 1999), indicates on its ability to infect species other than Centrarchidae. This is in contrast to its native range, where 0 . similis appears to be a specific parasite for $L$. gibbosus (Hoffman, 1998).

The hard parts of $O$. similis from the River Durance appeared to be a little smaller than those from native North American fish, similar to the findings of Roman (1953) or Ondračková et al. (2011) for the River Danube and its tributaries. European L. gibbosus have a much slower growth rate and a smaller adult size than those in the species' native range (Copp \& Fox, 2007). This difference in host size may provide a good explanation for the smaller size of 0 . similis hard parts in European waters. Alternatively, differences in water temperature between native and non-native range of $L$. gibbosus may also explain variation in size of the haptor hard parts of $O$. similis.

As in other European studies (e.g. Galli et al., 2005; Sterud \& Jørgensen, 2006; Ondračková et al., 2011), abundance of O. dispar in the River Durance was significantly lower than that for 0 . similis (but see Hockley et al., 2011). Just a few specimens were found in 2007, and only one specimen in 2010 . While the species occurs regularly it has a rare overall occurrence in non-native populations of $L$. gibbosus in Europe. Interestingly, O. dispar parasitises its host at higher frequencies in its native range than 0 . similis (Beverley-Burton \& Suriano, 1981; Wheeler \& Beverley-Burton, 1989). The two Actinocleidus species (A. oculatus and $A$. recurvatus) occurred relatively frequently in the River Durance. Both these species have been commonly documented in southern Europe, e.g. Italy (Galli et al., 2005) and southern France (Lambert, 1979). While $A$. recurvatus has recently been found in $L$. gibbosus populations in the middle River Danube (Croatia, Slovakia; Ondračková et al., 2011), occurrence of $A$. oculatus remains limited to southern Europe. Compared to $A$. recurvatus, abundance of $A$. oculatus was relatively high in both sampled years. A slightly higher prevalence and abundance of $A$. oculatus over $A$. recurvatus was also observed on the River Po in Italy (Galli et al., 2005). In North America, however, $A$. recurvatus tends to be a frequent species while $A$. oculatus occurs relatively rarely (Hanek \& Fernando, 1972; Beverley-Burton, 1981).

Three of the monogenean species found in this study, 0 . acer, $C$. robustus (Ancyrocephalidae) and G. macrochiri (Gyrodactylidae), were recorded in Europe for the first time. Both ancyrocephalid species occurred only accidentally. Only a one 0 . acer specimen was found in 2007 and low prevalence and abundance for C. robustus was detected in both examined years. In North America populations, both these species are relatively common (Hoffman \& Putz, 1964; Beverley-Burton \& Suriano, 1980a,b; Wheeller \& Beverley-Burton, 1989), suggesting that source populations for European introduction originated from regions with a relatively low occurrence of these parasite species. Alternatively, these species may be less tolerant to conditions occurring during transportation and acclimatisation in the new area, unlike 0 . similis, which is found in almost all European populations of L. gibbosus. Alternatively, as $L$. gibbosus introductions may be still taking place, these new parasites may only have been introduced recently. Unfortunately, there is little data available about the sites and years of recent introduction of $L$. gibbosus in French waterbodies. For a long time, this non-native fish species has been more-or-less ignored by parasitologists (except along the Danube River Basin), and this may also help explain the unexpectedly high monogenean diversity observed in our relatively small fish samples. 


\section{Acknowledgements}

This work was financed through Project No. P505/12/G112 of the Czech Science Foundation. We would like to thank André Gilles for help with fish collection; Martina Dávidová, Andrea Vetešníková-Šimková and Eva Řehulková for help with parasite processing and Kevin Roche for English correction.

\section{References}

Arnold, A. (1990): Eingebürgerte Fischarten. Zur Biologie und Verbreitung allochtoner Wildfische in Europa. Wittenberg Lutherstadt, Germany: Ziemsen Verlag, 144 pp.

Beverley-Burton, M. (1981): Actinocleidus oculatus (Mueller, 1934) and A. recurvatus Mizzele and Donahue, 1944 (Monogenea: Ancyrocephalidae) from Lepomis gibbosus L. (Pisces: Centrarchidae) in Ontario, Canada: anatomy, systematic position, and possible evolution. Can. J. Zool., 59: 1810 - 1817

Beverley-Burton, M. (1984): Monogenea and Turbellaria. In: Margolis, L., KabatA, Z. (Eds) Guide to the parasites of fishes of Canada. Part I. Ottawa, Canada: Fisheries and Oceans, Scientific Information and Publication Branch, pp: 5 - 209

Beverley-Burton, M., Suriano, D. M. (1980a): Haplocleidus dispar (Mueller, 1936) and Pterocleidus acer (Mueler, 1936) (Monogenea: Ancyrocephalinae) from Lepomis gibbosus L. (Pisces: Centrarchidae) in Ontario, Canada: anatomy and systematic position. Can. J. Zool., 58: $661-669$

Beverley-Burton, M., Suriano, D. M. (1980b): Cleidodiscus robustus Mueller, 1934 (Monogenea: Ancyrocephalinae) from Lepomis gibbosus L. (Pisces:Centrarchidae) in Ontario, Canada: anatomy and systematic position. Can. J. Zool., 58: $654-660$

Beverley-BuRton, M., Suriano, D. M. (1981): Onchocleidus ferox (Mueller, 1936) and O. similis Mueller, 1936 (Monogenea: Ancyrocephalidae) from Lepomis gibbosus L. (Pisces: Centrarchidae) in Ontario, Canada: anatomy, systematic position, and possible evolution. Can. J. Zool., 59: 1161 - 1171

Copp, G. H., Fox, M. G. (2007): Growth and life history traits of introduced Pumpkinseed (Lepomis gibbosus) in Europe, and the relevance to invasiveness potential. In: GHeRARDI, F. (Ed) Freshwater bioinvaders: profiles, distribution, and threats. Berlin, Germany: Springer, pp: 289 - 306

Galli, P., Stefani, F., Benzoni, F., Zullini, A. (2005): Introduction of alien host parasite complexes in a natural environment and the symbiota concept. Hydrobiologia 584: 293 - 299. DOI 10.1007/ s10750-005-3645-0

Grupcheva, G. I., Nedeva, I. L. (1999): Parasite fauna of the crucian carp (Carassius auratus gibelio Bloch) in the Zrebchevo reservoir (Bulgaria) Acta Zool. Bulg. 51: 115 - 122

Gusev, A. V. (1985): Monogenea. In: Bauer, O. N. (Ed) Key to the parasites of the freshwater fish fauna of the USSR. Leningrad, USSR: Nauka, 424 pp.

Hanek, G., Fernando, C. H. (1971): Monogenetic trematodes from the Bay of Quinte area, Ontario. II. Genus Gyrodactylus Nordmann, 1832. Can. J. Zool. 49: $1331-1341$

Hanek, G., Fernando, C. H. (1972): Monogenetic trematodes from the Bay of Quinte area, Ontario. III. Genera Actinocleidus, Cleido- discus, Urocleidus and Tetraonchus. Can. J. Zool. 56: 1235-1240 Hockley, F.A., Williams, C.F., Reading, A.J., Taylor, N.G.H., Cable, J. (2011): Parasite fauna of invasive pumpkinseed fish: first UK record of Onchocleidus dispar (Monogenea). Dis. Aquat. Org. 97: $65-73$

Hoffman, G. L., Putz, R. E. (1964): Studies on Gyrodactylus macrochiri n. sp. (Trematoda: Monogenea) from Lepomis macrochirus. Proc. Helminthol. Soc. Wash., 31: $76-82$

Hoffman, G. L. (1998): Parasites of North American freshwater fishes. Ithaca, USA: Cornell University Press, pp. 97-121

KIŠKAROLY, M. (1977): Study of the parasitofauna of freshwater fishes from fish ponds of Bosnia and Herzegovina. A. Monogeneous trematodes 1. Veterinaria 26: 195 - 208

LAMBERT, A. (1979): Postlarval changes of the sensory system among Dactylogyridea (Monogenea). Z. Parasiten. 58: 259 - 263 LIM, L. H. S., GiBson, D. I. (2008): Redescriptions of species of Ancyrocephaloides Yamaguti, 1938 (Monogenea: Ancyrocephalidae) from triacanthid fishes caught off Peninsular Malaysia and a report of their haptoral secretions. Syst. Parasitol., 69: 59 - 73. DOI 10.1007/s11230-007-9112-8

Malmberg, G. (1970): The excretory systems and the marginal hooks as a basis for systematics of Gyrodactylus (Trematoda, Monogenea). Ark. Zool., 23: 1 - 235

Mizzele, J. D., Hughes, R. C. (1938): The North American fresh-water Tetraonchinae. Am. Midl. Nat., 20: $341-353$

MoRAVEC, F. (2001): Checklist of the metazoan parasites of fishes of the Czech Republic and the Slovak Republic (1873-2000). Prague, Czech Republic: Academia, 168 pp.

Olivier, J-M., Carrel, G., Lamoroux, N., Dole-Olivier, M.-J., Malard, F., Bravard, J-P., Amoros, C. (2009): The Rhône River Basin. In: Tockner, K., Robinson C.-H., UeHLInger, U. (Eds) Rivers of Europe. London, UK: Academic Press in Elsevier, pp. 247 - 296

Ondračková, M., Dávidová, M., PŘikrylová, I., Pečínková, M. (2011): Monogenean parasites of introduced pumpkinseed Lepomis gibbosus (Centrarchidae) in the Danube River Basin. J. Helminthol, 435 - 441. DOI: 10.1017/S0022149X10000805

Piasecki, W., Falandysz, M. (1994): Preliminary survey on parasite fauna of pumpkinseed sunfish, Lepomis gibbosus (Linnaeus, 1758) ( Pisces, Teleostei, Centrarchidae) from warm-water discharge canal of the "Pomorzany" Power plant in Szczecin, Poland. Acta Ichthyolog. Piscatoria, 1: $86-98$

Price, C. E., Mura, A. (1969): The proposed synonymy of the monogenean genera Cleidodiscus Mueller, 1934 and Urocleidus Mueller, 1934 with the proposal of Cleidodiscus bychowskyi sp. n. Proc. Helminthol. Soc. Wash., 36: 52 - 55

Roman, E. (1953): Parasite fauna of sunfish (Lepomis gibbosus L.), acclimatized in Danube. Dokl. Akad. Nauk SSSR, 89: 765 - 768

Sterud, E., Jørgensen, A. (2006): Pumpkinseed Lepomis gibbosus (Linnaeus, 1758) (Centrarchidae) and associated parasites introduced to Norway. Aquat. Inv., 1: 278 - 280. DOI 10.3391/ ai.2006.1.4.10

Wheeler, T. A., Beverley-Burton, M. (1989): Systematics of Onchocleidus Mueller, 1936 (Monogenea: Ancyrocephalidae): generic revision. Can. J. Zool., 67: 136 - 157

Welcomme, R. L. (1981): Register of international transfers of inland fish species. FAO Fisheries Technical Paper 213: 1 - 120 